\title{
The Great Assembly of Vilnius, 1905
}

\section{Egidijus MOTIEKA}

The Great Assembly of Vilnius of 1905 (Didysis Vilniaus Seimas) or the Lithuanian Congress of Vilnius (Lietuvių Suvažiavimas Vilniuje) is important in several respects. It marks a remarkable frontier in the history of Lithuanian Revival, the climax of the national revolt of 1905-1906, and the beginning of the formation of the Lithuanian people's political aspirations.

The importance of the Assembly to the Lithuanian nation can hardly be overestimated. At this Assembly the delegates of the whole nation declared their determination to seek Lithuania's autonomy within its ethnographic boundaries. This meant the beginning of a new ethno-social community eager to solve its own fate. Thus the model of a new modern nation, which had developed since the times of the newspaper Aušra was transferred from the sphere of public thought to real political declarations and activities. Nevertheless it is obvious that this did not mean the rejection of other possible models for Lithuanian ethno-political structures.

The Great Assembly of Vilnius specified the political objectives of the revolt of 1905 , defining the minimum of ethnopolitical demands. Lithuanian autonomy was understood as an interim phase in the road to complete independence. Therefore, a study of the Great Assembly of Vilnius offers new opportunities in the analysis of the genesis of the Act of February 16, 1918, and helps to define the relationship between embodiment of Lithuanian statehood (the national state) and the old Lithuanian polity - the Grand Duchy of Lithuania.

Apart from this, the analysis of this problem offers a way to disclose some qualities of Russian politics in the "imperial hinterland" and to make known the methods and measures which subsequently were repeatedly used by a legal successor of the Russian empire, the Soviet Union in its international relations with Lithuania, as well as in domestic national politics.

In order to analyse the developments in Lithuania during 1905-1906, it is necessary to determine in what respects the Great Assembly of Vilnius differed from the national revolution and the general revolutionary process of 1905 . The revolt of 1905 in Lithuania represented the revolutionary movement of all Lithuanian ethnic groups, social strata and parties, directed against Russian absolutism, for cardinal or moderate reforms. On the general Lithuanian scale it 
was a rather chaotic process involving ethnic communities and political and social forces, that pursued totally different goals. The national revolt was also a part of the general revolutionary movement in Lithuania as well as a totally independent phenomenon that had evolved from the Lithuanian national movement and it had quite specific objectives. The revolt of 1905 was a combination of a variety of movements, while the national revolution was a deliberate action by the part of whole of Lithuanian society aimed at restoring Lithuanian statehood on the basis of the Lithuanian ethnos. The primary goal of the national revolutionary movement was to consolidate the Lithuanian public and to win the autonomy of Lithuania. This movement was represented by the already formed Lithuanian political structure embracing Lithuanian political parties and groupings, and the Lithuanian intelligentsia as a whole; its social basis was the Lithuanian peasantry. The Great Assembly of Vilnius was already a part of the Lithuanian national revolt, and its highest point. Therefore, it would be a highly formal solution of the problem to dissociate the national revolt from the Great Assembly of Vilnius. The organization of the Assembly (i.e. Congress) was aimed at assessing the possibilities which faced the Lithuanian national movement during the period of national revolt.

The archival material illuminating the Great Assembly of Vilnius is not very rich. This deficiency is compensated by the memoirs of Assembly delegates which were lavishly published throughout the period of the Lithuanian Republic (1918-1940). Yet until recently, the problems of the Assembly have been more an object of popular writing than of scholarly research. The Great Assembly of Vilnius has not yet had the attention of a monograph. Among the most active researchers of the Assembly have been M. Riomeris (Römer), L. Gira, P. Klimaitis, M. Biržiška, J. Gabrys-Paršaitis, P. Ruseckas, A. Tyla and P. Čepènas ${ }^{1}$. Their works and some others are not comprehensive, and only some of the problems have received broader coverage: the national revolt in the Lithuanian countryside, the activities of the political parties late in 1905, and the implementation of the Assembly's decisions and their significance for the restoration of Lithuanian statehood. Much less attention has been paid to organizational aspects - the activities of the Lithuanian Organizational Bureau of Vilnius and the Organizing Committee of the Congress (OK), or the Lithuanian Memorandum of November 1905 to the Russian government. The data on the proceedings

${ }^{1}$ M. Römer, Litwa. Studyum o odrodzeniu narodu litewskiego, Lwów, 1908, 339-436; P. Klimaitis, Didysis Vilniaus Seimas, Židinys, 1, 1931, 43-56; 2, 1931, 146-160; 4, 1931, 365-376; P. Ruseckas, Didysis Vilniaus Seimas, Vilnius, 1930; L. Gira, Didysis Vilniaus Seimas, Lietuvos Aidas, 6, 8, 9, 12, 17, 18, 19, 23, 26, 1917; 1, 39, 40, 1918. J. GabrysParšaitis, Didysis Vilniaus Seimas ir jo reikšmè Lietuvai, Naujoji Romuva, 47, 48, 50, 1936; 1, 3, 7, 1937; P. Čepènas, Naujuju laiku Lietuvos istorija, I, Chicago, 1977, 321-396; M. B-ka [M. Biržiška], Didysis Vilniaus seimas, in Lietuviškoji enciklopedija, VI, Kaunas, 1937, 690-705; A. Tyla, 1905 m. revoliucija Lietuvos kaime, Vilnius, 1968, 74-92. 
of the Congress are very scanty, too, and no detailed analysis of the resolutions can be found.

Late in the 19th and early in the 20th century, the newly-revived Lithuanian nation entered the political phase of the national movement. This had as its typical characteristics the politization of national ideology, the founding of political parties, and the tremendous influence of the periodic press on the political thought and political culture.

On the eve of the revolt of 1905 Lithuanian society was already marked by the existence of two major political currents: radicals (the Lithuanian Social Democratic Party (LSDP) and the Lithuanian Democratic Party (LDP); before 1906 the LDP was a party of rightwing radicals and conservatives (moderate liberals who after the Lithuanian Congress gathered into the National Lithuanian Democratic Party (Tautiškoji lietuviu Demokratų Partija, abbr. TLDP, and the Christian Democrats). All these movements raised a common demand for Lithuanian autonomy, offering different tactics for winning this autonomy.

The Russo-Japanese War of 1904-1905 and the ensuing Revolution of 1905 in Russia gave a large impetus to the politicization of the Lithuanian national movement. Yet already in late 1904 - early 1905 a problem of integration between the Lithuanian people and Lithuanian political structures arose. As public life was gaining momentum, the Lithuanian nobility again joined in political activities; they had retained the political self-consciousness of the former state the GDL, with its political and cultural traditions, and used these as a basis for the construction of the different options for the restoration of Lithuanian statehood, from an independent Lithuania (the GDL, i.e. Lithuania and "Belorussia") to projects for total integration with Poland. As the Lithuanian political parties (LDP and LSDP) established contact with the Polish political democratic forces of Lithuania (respectively with the "krajowscy" socio-political movement and the Polish Socialist Party in Lithuania), two conceptions for the restoration of Lithuanian statehood became evident: one within the ethnographic boundaries of Lithuania and another those within of the GDL. Until autumn 1905 no compromise had been achieved between those two models for the restoration of the Lithuanian state.

During January-September 1905 the national-revolutionary movement involved ever broader sections of the Lithuanian public. The LSDP and the LDP managed to consolidate their positions. During the summer of 1905 the latter took to establishing its autonomous organizations - the Lithuanian Teachers' Association (Lietuvos Mokytoju Susivienijimas, abbr. LMS) and the Lithuanian Peasants' Union (Lietuvos Valstiečiu Sajunga, abbr. LVS). However, as the Social Democrats and Democrats were solving their organizational problems and competing for the influence on Lithuanian society, the wing of Moderate Liberals (National Liberals) gained strength and in 
October 1904 gathered around the Vilniaus žinios daily. This grouping also propagated the concept, "Lithuania within its ethnographic boundaries" and emphasized the priority of the Lithuanian ethnos in the restoration of Lithuanian statehood, calling for measures to achieve a possibly more rapid implementation of the plan. During 1905 Vilniaus žinios became the centre of cultural-organizational activities and claimed to be the "nation's unifier".

In September 1905 the National Democrats made their first steps towards political hegemony. It was thanks to their effort that the Lithuanian Organizational Bureau was established in Vilnius. This was supposed to co-ordinate the activities of Lithuanian parties and groupings located in Vilnius ${ }^{2}$.

The idea of the Lithuanian Congress developed from that of the Lithuanian Constituent Assembly which since the beginning of 1905 had been actively promulgated by the LSDP, and partly by the LDP. The true author of the idea of a Lithuanian Congress was J. Basanavičius, leader of the national democrats. His idea, proposed late in October 1905, was initially supported by J. Kriaučiūnas, and somewhat later by the whole political grouping of Vilniaus žinios. In J. Basanavičius' opinion, the objective of the Lithuanian congress was to discuss the political situation in Lithuania and Russia and the cultural and political aspirations of the Lithuanian nation, as well as to consolidate Lithuanian society in its fight for the autonomy of Lithuania. All Lithuanian political parties and groupings were summoned to work towards the realization of this scheme. This resulted in the formation of the Organizing Committee on October 19, 1905. Its bulk was made up of the National Democrats. Representatives of the LDP and the LSDP were also elected, yet later on, the LSDP refused to participate in the Committee's work. On October 27, 1905, the OC issued a "Proclamation to the Lithuanian People", calling the nation's representatives to attend the Lithuanian Congress in Vilnius on November 21-22 (December 4-5 - New style calendar). The Proclamation managed to combine the fairly moderate political aims of the National Democrats with the more radical aspirations of the LDP. However, the statement of the former prevailed. The Proclamation was based on the Tsar's manifesto of October 17 (30), yet for fear of the reprisals by local authorities, open political declarations were avoided.

Therefore, already during the first days of the OC's work, a coalition between the Lithuanian political parties and groupings was established. It embraced the LDP, LMS, LVS and National Democrats as well as unaligned members of the intelligentsia. For the time being the coalition did not involve the LSDP or Christian Democrats. The

${ }^{2}$ R. Miknys, E. Motieka, Tautiškoji lietuvių demokratų partija: idėjinès-politinès kūrimosi aplinkybès, in Lietuviu atgimimo istorijos studijos [LAIS], I, 1990, 94-99. 
Social Democrats accused the OC of moderation, while the Christian Democrats focused on their own organizational problems ${ }^{3}$.

The next stage in the work of the OC was the preparation and sending of the Memorandum to the Russian Government (October 28 - November 5 (November 10-18), 1905). The Memorandum aimed at examining the attitude of the Russian administration towards the political aspirations of the Lithuanian nation, rather than convening a Lithuanian Congress. The Memorandum was the first document to be written by Lithuanian statesmen: it explained the historic rights of the Lithuanian nation and related concrete cultural and political demands. At the same time the Memorandum offered a qualified analysis of the historical traditions of Lithuanian statehood and justified the desire of the revived Lithuanian nation to continue these traditions. The LDP spoke out against sending this memorandum to the Russian government, arguing that this would be just one of the numerous appeals addressed to the Russian administration. The reaction of senior Russian officials to the Memorandum was astonishing: it was immediately published in the government paper, Pravitelstvennyj Vestnik. The Russian authorities, however, did not publish those articles of the Memorandum which emphasized the historic traditions of Lithuanian statehood, and instead focused attention on the paragraphs which declared Lithuania's ethnopolitical differentiation from Poland. Nevertheless, the significance of the Memorandum was enormous - the Lithuanian statesmen realized that the Russian government was not going to pose any obstacles to holding the Congress ${ }^{4}$.

On November 6-13 (19-25) the 6th Congress of Russian rural areas and urban activists was held in Moscow. It was also attended by Lithuanian politicians who sought to find out the attitude of Russian and Polish democratic strata towards the desire of the Lithuanian national movement to establish Lithuania's political autonomy (within ethnographic boundaries). The idea of Lithuanian autonomy found approval, yet the Lithuanian delegates were requested to hold back from its immediate declaration. The Congress also discussed the possibility of convening a joint Lithuanian-Polish congress, yet no further discussions of this kind took place afterwards.

As the "Proclamation" was announced, Lithuanian society started preparations for the Congress. Rural districts, parishes and prefectures (seniūnijos) began to organize meetings and demonstrations, passed resolutions addressed to the Congress, and elections of delegates. This proved the growing influence of Lithuanian political parties and groupings, generally the Lithuanian intelligentsia, on the Lithuanian countryside. Clearly Lithuanian intellectuals and peasants

${ }^{3}$ E. Motieka, Didysis Vilniaus Seimas: ideja, iniciatyva, organizavimas, Proskyna, 4(7), 1990, 233-239.

${ }^{4}$ E. Motieka, Didžiojo Vilniaus seimo preliudija: Memorandumas Rusijos vyriausybei, in LAIS, III, 199-230. 
had different views of the tasks that the nation was facing, yet both these social strata perceived themselves as part of one and the same ethnopolitical community. As the Congress drew nearer, the mutual antagonism between the Lithuanian political groupings was fading. Lithuania was involved in the ethnopolitical movement that also forced the LSDP and Christian Democrats to change their tactics; they launched active preparations for the Congress. It became obvious that the entire Lithuanian political structure of the period would be represented at the Congress. The OC continued its activities, constantly reminding readers of the Congress in Vilniaus žinios. The initiative in the OK was taken by the National Democrats. Right before the Congress, a new, second programme was accepted. It paid greater attention to the political problems of Lithuania.

Thus within a very short time the National Democrats had succeeded in mobilising Lithuanian political forces and Lithuanian society as a whole. As the idea of a Lithuanian Congress was set forth and prerequisites were created for its successful realization, a partial isolation from the non-Lithuanian population of the country took place. This meant that ethnopolitically Lithuania would be integrated in a different way than was imagined by the LSDP and LDP, who preferred a Constituent Assembly. It became clear that the fate of Lithuanian autonomy and the Constituent Assembly would largely depend on the forthcoming Lithuanian forum 5 .

The Congress was attended by 2000 delegates, among whom 1000 were representatives of Lithuanian rural districts, parishes and villages. The most sizeable deputation came from Aukštaitija, Suvalkija and Žemaitija, with smaller groups from Dzūkija and the western districts of the Province of Vilnius. Also present were Lithuanians from St. Petersburg, Moscow, Riga, Liepaja, Mintauja, Dorpat, Tallinn, Kiev, Odessa, Voronezh, and Warsaw. There was a representative of Prussian Lithuanians too. The Congress was supported by Lithuanian Americans, who sent telegrams of greeting. During the days of the Congress they organized meetings and rallies in the USA. Several delegates were from Poland and Belorussia (peasants), the eastern districts of the Province of Vilnius, as well as the Provinces of Grodno and Minsk.

The Congress represented the entire Lithuanian social spectrum, most delegates coming from the peasantry $(50-70 \%$ of the participants) and intelligentsia (30-40\%). Workers. landlords and artisans were much more sparse. All Lithuanian political parties (the LSDP and LDP) and groupings (the LVS, LMS, National Democrats and Christian Democrats) took part. There were representatives of the "krajowscy" socio-political movement, "Bund", the Polish Socialist Party of Lithuania and Belorussian socialist "hromada".

${ }^{5}$ E. Motieka, Nuo Lietuvių suvažiavimo Vilniuje iki Didžiojo Vilniaus seimo: istoriografinè Suvažiavimo pavadinimo analizè, in LAIS, IV, 275-288. 
The Congress opened on the morning of November 21 (December 4), 1905, with J. Basanavičius's address to the audience. At the beginning the $O C$ had to transfer its powers to the Congress, and the latter, to the elected presidium. The elections to the presidium already showed the readiness of the parties and political groupings to contest their influence. There was considerable squabbling between the interests of National Democrats and Social Democrats who were seeking supremacy in the presidium. Eventually, a presidium of five persons was elected: J. Basanavičius (unaligned), J. Stankūnas (farmers), A. Smetona (LDP), S. Kairys (LSDP), and P. Būčys (Christian Democrats).

The Congress was offered two agendas - by the $\mathrm{OC}$ and the LSDP. The OC' 's programme was fundamental, based on the idea of essential reforms in the country that had to lead to Lithuania's autonomy. It was not, however, a programme of concrete political activities. At its basis lay just a premise of political and cultural demands without any insight of how to put these demands into effect. The LSDP programme was both more constructive and more radical. It stressed the necessity of establishing a legal basis to the Congress and suggested a very constructive plan for discussing the implementation of statehood. The Congress passed a compromise decision: the confirmed agenda combined the key points of both the OC and LSDP programmes.

The main aftermath of the first session ("Reports from the Province. Evaluation of the Political Situation in Lithuania and Russia") was the realization that all political parties and groupings were in favour of cardinal reforms both in the whole Russian empire and in Lithuania. These reorganizations were associated with the subsequent development of society's democratization and formulation of the political objectives of the Lithuanian nation.

The second session ("Lithuanian Autonomy and Tactics for Gaining It") was held in the evening of the same day. All parties and groupings supported the intention of creating Lithuanian autonomy (within ethnographic boundaries) (the minimum programme). Only the tactical measures offered were different: the LSDP, LDP, LVS, LMS advocated a revolutionary fight (the Social Democrats - even an armed one), while Christian Democrats and National Democrats called for a fight using legal political means.

The third ("The Agrarian Question") and fourth ("The Question of Lithuanian Schools. The Passing of Congress Resolutions") sessions toOC place on the second day - November 22 (December 5), 1905. In dealing with agrarian problems, two positions conflicted with one another: 1) all Lithuanian land should be passed to the whole nation and only afterwards distributed to those who culti-

${ }^{\circ}$ E. Motieka, Didysis Vilniaus seimas (Unpublished Ph. D. thesis, University of Vilnius, 1993), 169-191. 
vate it; 2) the current ownership of private property should be preserved. Most speakers at this session were peasants. Neither the political parties, nor groupings paid any greater attention to this issue. They were of the opinion that the agrarian question could be heard only at the Lithuanian Constituent Diet (Lietuvos Steigiamasis Seimas). Therefore no final decisions were made.

On the issue of schools, the Congress supported the tactics proposed by P. Klimaitis: Russian schools with Lithuanian teachers were to be allowed to continue their work, only the language of instruction had to be Lithuanian; the schools in which the teaching staff was Russian were to be closed or the Russian teachers were to be replaced by Lithuanian ones; church schools were to be abolished. This meant a further Lithuanization of primary schools and the creation of prerequisites for a fundamental reform of the education system in the case of the successful execution of the projects concerning Lithuanian autonomy ${ }^{7}$.

Late in the night of November 22 (December 5) the presidium completed the editing of the Congress resolutions drafted by the editorial commission. They were passed unanimously. Later J. Basanavičius presented an addendum to the Congress resolutions, undiscussed at the presidium and the editorial commission - a protest against the Church's policy of polonizing Lithuanians in the diocese of Vilnius. The Congress voted unanimously for this resolution too ${ }^{8}$.

The success of the Congress was determinated by a rational selection of the presidium members and the fruitful performance of the LDP as well as the LVS in combining the very resolute positions of the Social Democrats and National Democrats with those of the Christian Democrats.

In the resolutions the Russian government was declared to be the worst enemy, and intentions were expressed to join forces with other nations of the Russian empire against it. They also contained a statement of the principles of developing Lithuanian autonomy: a demand was raised for an autonomous Lithuania (within its ethnographic boundaries) with a democratically elected Diet at Vilnius; an opportunity was provided for the inhabitants of the ethnographic outskirts to decide themselves about their belonging to the Lithuanian autonomy, yet quite a firm resolution was made concerning the annexation of the Lithuanian districts of the Suvalkai province; federal ties with "neighbouring countries" were envisaged. Alongside rather abstract demands to unite the "efforts of Lithuanian political parties in the fight against Russian government" and later on "to join with all the other nations of Russia", several effective measures were designed for starting the reorganization of Lithuanian district boards, courts of law and schools.

${ }^{7}$ Ibid., 192-217.

${ }^{8}$ Pirmojo Lietuvių Tautos Atstovy suvažiavimo nutarimai, Vilniaus žinios, 276, 24.11.1905 (07.12). 
The Congress resolutions were not proclamatory (i.e. they did not declare the restoration of Lithuanian statehood in one form or another) but demanding. Although expressing the will of the Lithuanian nation, they did not encourage the formation of an active political subject capable of reacting not only to Russian politics but also of creating juridical and factual prerequisites for the formation of a new state and political structures. The development of this kind of a political subject was only in the draft stage. Thus the Congress resolutions were the minimum demands of the Lithuanian nation.

The Lithuanian Congress accelerated the formation of Lithuanian political groupings into parties. A constituent congress of the LVS and a meeting of Lithuanians from the Suvalkai province were held during the Congress, and as soon as it was closed - meetings of the LSDP and Christian Democrats, as well as the 2nd LMS Congress and a constituent meeting of the National Lithuanian Democratic Party. These congresses and meetings passed resolutions that made amendments in the programs of the aforementioned political parties and groupings, taking into consideration the decisions of the Congress. The resolutions of the parties were a specific supplement to Congress decisions and contributed to their implementation.

As the Congress failed to establish an organizing centre which would guarantee the implementation and control of the resolutions, the role of the Lithuanian national revolutionary movement after the Congress was claimed by the National Lithuanian Democratic Party. It, however, was a party of intellectuals, without any stronger organizational structures or supporters in the Lithuanian countryside. Besides, it was not backed by other Lithuanian political parties and groupings. Fruitless attempts to establish a coordinative body did not mean that, after the Congress, parties dissociated from one another and were not carrying out its decisions. They were being implemented yet their vagueness allowed the parties to freely interpret them. The situation arose that in the Lithuanian countryside, many actions against the local Russian administration were carried out by joint efforts, while party centres did not keep in any closer contact, although there were not any mutual conflicts.

Congress decisions were broadcast within a few days after the Congress. The scenario of replacing the old government was similar all across Lithuania: as the local population became acquainted with the decisions, the old district counsel was dismissed and a new one elected. Courts and schools were reorganized. These constructive reorganizations were accompanied by some other reforms that warranted the functioning of the new local power: the police was disarmed and replaced by a peasant militia and self-defence units; instructions on the use of weapons were given; spies and agents provocateurs were flushed out and frequently eliminated; funds were collected for the purchasing of arms; administration orders were ignored, etc. 
The decisions of the Congress were actively broadcast and carried out by the LSDP, LVS and LMS, and partly by the LDP. The contribution of the National Democrats and Christian Democrats was only fragmentary. The essential difference in reforms in the Lithuanian countryside before the Congress and after was that after the Congress the reorganization of local administrative bodies was coordinated (as it was based on Congress decisions) and massive (covering the whole of Lithuania within its ethnographic boundaries). However, only Lithuanian rural districts were touched by reconstruction, while capitals of provinces and gubernias continued to be run by the Russian administration. The following turn of events in the Lithuanian countryside ought to be noted. The major reconstructions occurred over November 23 - December 6 (December 6-19), 1905. December 7-20, 1905 (December 201905 - January 2, 1906) was the period of consolidation of the new district administration. The end of December, 1905 (old style) marked the beginning of mass reprisals by the Russian government and the period of the liquidation of the new local power which lasted until February 1906. The resistence of the Lithuanian countryside was finally crushed in April 1906. The reprisals were a key factor in destroying the gains of the national revolution. Lithuanian society, above all its most moderate strata, was also negatively affected by the popularization of the State Duma as an allegedly democratic body which was bound to consolidate democratic reforms. So little by little legal ways to carry out political fight came to be propagated. Already in December 1905 - January 1906 this direction was taken by the National Democrats and Christian Democrats, followed by the LDP, LMS and LVS. Only the LSDP continued to offer active resistance to Russian power until the summer of 1906.

Although Congress decisions did not call people to arms, during the reconstruction of the Lithuanian rural districts, armed operations were a natural consequence. Nevertheless, in the Lithuanian countryside the peculiarities of a classical armed rebellion coexisted with specifically "Lithuanian" ones. Trained military units did not exist; there was no uniform leadership that could oppose the regular army, carry out larger military operations or most important, use military measures in executing tactically and strategically motivated tasks and not confine itself to mere control over the local district administration.

At the beginning of the functioning of the Lithuanian Congress OC, local government did not pay any special attention to it. Besides, the Russian administration partly supported the cultural and even the minimal political aspirations of Lithuanians, seeking to prevent any affiliation between Lithuanian and Polish national movements, and also to separate the Lithuanian national movement from the political forces of Lithuanian Poles. Therefore the "Proclamation to the Lithuanian Nation" and Memorandum did not alarm the local authorities. Yet during the last week before the Congress OC was per- 
forming very actively, the government became anxious. Attempts to appease Lithuanian public figures through declarations or backstage negotiations turned out to be unsuccessful, and local authorities did not dare to ban the Lithuanian Congress. During the Congress the police kept a close watch on its work and informed the GovernorGeneral of Vilnius. As the implementation of the Congress decisions started, it became clear to the local Russian administration that the Lithuanian movement could not be suppressed by peaceful methods. Retaliatory actions began in the middle of December 1905. To this end the punitive detachments operating in the provinces of Kaunas and partly of Suvalkai (in the latter martial law was introduced after the Congress) were summoned for help. By February 1906 the punitive detachments had managed to restore the former government and to suppress the main centres of the national revolutionary movement, although reprisals continued well into April 1906. Their success was due to the weakness of the armed participants of the national revolt and the arrest of its chief organizers 9 .

The Lithuanian congress activated the non-Lithuanianspeaking public of Lithuania - Belorussians, Jews, Russians but, above all, Polish-speaking Lithuanians and Lithuanian Poles. In December 1905 - February 1906 the political strata of Lithuanian Poles sought contacts with the Lithuanian national movement. This became particularly obvious in mid-December 1905, when Lithuanian landlords noblemen, considering the Lithuanian congress merely as an assembly of Lithuanian-speaking society, made an attempt to organize a joint meeting of Lithuanian and Polish speaking public representatives. Although this congress did take place (in scholarship it is referred to as the "anti-assembly" (Lith. antiseimas), in effect this action was not success. Lithuanian political parties did not pay any special attention to this congress, and Lithuanian landlords were not adequately prepared either. Again there was a clash between the two models for the restoration of Lithuanian statehood - within Lithuania's ethnographic boundaries and within the GDL. This problem also emerged in January-February 1906 as the Lithuanian-Belorussian Constitutional Catholic Party was trying to unite Lithuanian and Belorussian societies.

The Congress had a tremendous effect on the Lithuanians in the United States. Its direct aftermath was the Lithuanian-American Congress at Philadelphia in February 1906. Its aim was to consolidate different American Lithuanian political forces and to discuss ways of offering more active assistance to the ongoing national revolution in Lithuania.

As concerns the significance of the Assembly to the Lithuanian public, two levels of this problem can be singled out: 1) the direct influence of the Assembly on the cultural and political situation

${ }^{9}$ E. Motieka, Didysis Vilniaus seimas..., 355-378. 
in Lithuania; 2) the effect of the Assembly on the Lithuanian nation's political-civil and state tendencies.

No doubt, the gains made by the Great Assembly of Vilnius and the national revolt were great: Lithuanian teachers were allowed to work at primary schools, the Lithuanian language became a separate discipline (it was introduced in the Catholic Theological Seminary of Vilnius and also in separate grammar schools), the press was given more freedom, the foundation of different economic and cultural societies was permitted, etc. In general, during 1905-1906 the Russian administration lifted many cultural restrictions. It is even possible to contend that Lithuanian cultural life between 1906 and 1914 resembled cultural autonomy. Political restriction remained although Lithuanian political parties and groupings, except the LSDP, were not limited in action.

More important, however, is the second aspect of the significance of the Assembly. It was the first real political step in drafting the principles of the restoration of Lithuanian statehood. The Assembly drew a strategic plan for the restoration of the Lithuanian state on the basis of the Lithuanian ethnos (the modern Lithuanian nation) on the ethnographic Lithuanian territory with its capital at Vilnius.

The Great Assembly of Vilnius confirmed the final picture of the Lithuanian political structure. It was also the beginning of a new stage in political development, when the stratagems and tactics of political parties and groupings could be corrected only with direct or indirect consideration of the interests of other groupings. It marked the whole subsequent political evolution of Lithuania until the restoration of the Lithuanian state itself.

The Assembly marks a new stage in the formation of a modern legally free individual among equals, which was later, between 1917 and 1920, completed by the creation of a civil society. A civil society is one where the citizen is aware of his freedom and his rights and duties as a citizen. It is also a society that recognises its own ethnocultural, ethnosocial and ethnopolitical identity.

Undoubtedly Lithuanian society during the time of the Assembly did not meet the criteria of an ideal civil society. The Assembly's audience was the Lithuanian public united on ethnolinguistic (ethnocultural) and ethnopolitical (the demand for Lithuanian autonomy within its ethnographic boundaries) grounds. However, a significant part of the Lithuanian people, which also identified itself as Lithuanian were excluded from the Congress, because of differences in the ethnocultural (e.g. total or partial ignorance of the Lithuanian language, orientation to cultural values that were created in the forms of Polish culture) and ethnopolitical (e.g. plans to restore either the GDL or the Polish-Lithuanian commonwealth) tendencies. Basically it was the Lithuanian nobility that was scantily represented at the Assembly of Vilnius, i.e. the public stratum that had inherited all civil traditions. This group still had to be attracted. In this respect 
the Assembly society was a society whose concept was still subject to change.

The Lithuanian nation whose political tendencies were then expressed by the independent Lithuanian national movement gradually became a political subject, and this was partly confirmed by the Great Assembly of Vilnius. The realization was also developing that the entire Lithuanian nation, although split into estates and social strata, was the inheritor and guardian of the political and cultural traditions of the ancient state (the former GDL).

The Assembly as a Lithuanian political action registered just one of the several ethnopolitical tendencies of Lithuania. This political orientation could be corrected as the Lithuanian congress expressed only the Lithuanian attitude on the eve of the drafted Constituent Assembly of Lithuania. On the other hand, the Assembly revealed a political orientation which under the political circumstances of the 20th century had the broadest perspectives, as it helped to bring the principles of citizenship into life.

The tremendous significance of the Assembly for enhancing the political objectives, for the development of a civil society and the formation of new traditions of parliamentarianism was the reason why shortly after the Congress its historic name - the Lithuanian Congress in Vilnius - was replaced by far more momentous scholarly term - the Great Assembly of Vilnius. In the long run this term became the norm.

Although the Assembly clearly expressed the priority of ethnographic values over historic ones, the statements of separate parties or individuals (the LDP, LSDP, J. Basanavičius et al.), as well as contacts with Lithuanian and Belorussian political forces devoted to the restoration of the historic Lithuania (GDL), showed that the problem of the succession of the traditions of Lithuanian statehood was being resolved. However, claims were only made to the "Lithuanian" legacy of the GDL. The Great Assembly of Vilnius was an expression of the formation of the nation's political objectives. Although the problem of Lithuanian statehood was the most important issue of the Assembly, matters of state inheritance were not discussed here. However, sooner or later this problem had to be faced by the leaders of the national movement. Its urgency was well illustrated by the fact that the principle of national self-determination, which appeared in 1905-1906, was perceived by the ruling strata of the Western countries as a requirement for cultural autonomy. Hence a nation that could not depend on statehood traditions was only able to pretend to cultural or political autonomy, at best. Therefore, the successful formation of the Lithuanian people's political aspirations had to rely on political and cultural maturity, an insight into the historic legacy of the GDL and its appropriation, as well as on the unstable geopolitical situation whose eventual shifts raised the hope of restoring the Lithuanian state. 